\title{
Evaluation of learning, reaction and impact of corporate training at work
}

\author{
Maria Cecília dos Santos Queiroz de Araujo 1,* (D), Gardênia da Silva Abbad², \\ $\&$ Thais Rodrigues de Freitas ${ }^{2}$ \\ ${ }^{1}$ Agência Nacional de Vigilância Sanitária, Brasília, DF, Brasil \\ ${ }^{2}$ Universidade de Brasília, Brasília, DF, Brasil
}

\begin{abstract}
This research aimed to evaluate individual level reaction, learning using situational tests and impact of three trainings conducted at a regulatory agency, analyzing: individuals' previous experiences in trainings; customers' sociodemographic variables; support to transfer; and relationships between the variables. The survey comprised 211 respondents, five instruments for data collection, and descriptive and non-parametric statistics for data analysis. The results indicated that: there is no significant correlation between learning and impact self-assessment; there is a significant correlation between reaction assessment and impact self-assessment; and the participants' psychosocial support assessment was significantly related to their impact self-assessments. The main contributions and limitations of the study are discussed.
\end{abstract}

KEYWORDS: reactions, learning, training impact at work

\section{Avaliação de aprendizagem, reação e impacto de treinamentos corporativos no trabalho}

\begin{abstract}
RESUMO - Esta pesquisa teve como objetivo avaliar a reação, a aprendizagem por meio de testes situacionais e o impacto no nível do indivíduo de três treinamentos realizados em uma Agência Reguladora, analisando a experiência dos indivíduos na temática dos treinamentos, as variáveis sociodemográficas, o suporte à transferência e as relações entre as variáveis. A pesquisa contou com 211 respondentes, cinco instrumentos para coleta de dados e estatísticas descritivas e não-paramétricas para análise dos dados. Os resultados indicaram que não há correlação significativa entre aprendizagem e autoavaliação de impacto; há correlação significativa entre reação e autoavaliação de impacto; a avaliação de suporte psicossocial pelos participantes esteve significativamente relacionada com a autoavaliação de impacto. São discutidas as principais contribuições e limitações do estudo.
\end{abstract}

PALAVRAS-CHAVE: avaliação de treinamento, reações, aprendizagem, impacto do treinamento no trabalho

In recent years, by virtue of the great changes taking place in the society, the acquisition, maintenance and transfer of new learning to work are considered strategic tools and tools to ensure sustainability of organizations, and also as an instrument of employability for workers (Abbad \& Borges-Andrade, 2014). Training, development and education (TD\&E) actions are among the most well-known and usual strategies for learning induction in organizations. These are defined as actions planned and systematically executed by organizations, aiming at the acquisition of knowledge, skills and attitudes - CHAs required to overcome job performance deficiencies, to prepare employees for new jobs, adapt the workforce to introduce new technologies, and promote the free growth of members of an organization (Abbad \& Borges-Andrade, 2004).

TD\&E actions are defined as formal learning strategies that may vary in length, complexity and proximity to the strategic objectives, among other attributes. Training is a concept adopted for actions aimed at improving the current performance of a worker in the position or function they hold. Development refers to actions aimed

*E-mail: ceciliasqs@gmail.com

- Submetido: 23/08/2017; Revisado: 13/09/2017; Aceito: 04/10/2017. 
at the employee's personal and professional growth, not directly related to the activities currently performed or even with future activities. The concept of Education, finally, consists in preparing the employee for the development of activities that will be performed in the future (Vargas \& Abbad, 2006).

Models and tools for assessing TD\&E actions were created to optimize the use of resources, increase the effectiveness of instructional systems and produce scientific knowledge about training-induced learning. According to Meneses, Zerbini and Abbad (2011), training assessment has several purposes, including: (1) provide systematic information on gaps in individual learning and instructors' performance; (2) identify planning failures; (3) verify if training was positive for individuals and organizations in terms of applicability and utility; and (4) inform to which extent skills learned are being applied in the work or professional life of individuals and which aspects facilitate or hinder this process.

Despite the increasing production of knowledge about training and its effects on people, organizations and society, there is still relatively little research investigating the relationship between learning, reactions and impact of training on the work of the graduate. Results from national and foreign research have shown that the relationships between trainee reactions, learning, and the impact of training on graduate work are not consistent, especially as regards the relationship between learning and the two other effects or levels (reactions and impact). In addition, there are studies where learning is not correlated with the impact of training on the graduate work, in others this correlation exists but is weak, in opposition to the assumptions of traditional assessment models. These inconsistencies may be partially related to flaws in learning assessment measures, which are commonly based on self-assessments without evidence of validity or on declarative knowledge tests that do not measure the application of knowledge, problem solving, or the creation of new work methods, more complex and aligned with the scenarios of practice and the actual work of the trainee in the organization.
The analysis of the literature on TD\&E assessment also shows that: (1) learning measures, reactions and impact of work-related training commonly used in research are made up by questionnaires applied to training participants and graduates; (2) There are relatively few surveys that adopt more than one human source of assessment other than training or graduate, such as bosses, peers, and colleagues; (3) learning has been measured by instruments with little evidence of validity, with levels of complexity incompatible with the training objectives. These gaps and methodological flaws hinder the development of theoretical evaluation models, which have not advanced in the last two decades as regards the production of knowledge about learning in trainings, neither about the relationship between this effect and reactions and impact of training at work.

In this context, this research also intends to fill some of the gaps pointed out in the research agendas in the field of TD\&E, such as those that suggest the use of more than one source of information for data collection rather than using only self-report (Abbad \& Meneses, 2003; Galanou \& Priporas, 2009; Homklin, Takahashi \& Techakanont, 2014; Pham, Segers \& Gijselaers, 2012) and the inclusion of little explored variables in research, such as the subjects' previous experience on the topic of the training.

This research is part of the effort to build and deepen knowledge about training effects at the level of the individual trained. It is inserted in the field of TD\&E assessment and aims to: (1) evaluate participants' reactions, learning and the impact of training on the performance of graduates of three trainings; (2) measure learning through situational tests based on practical cases, designed based on the instructional objectives of the trainings; (3) analyze the relationships between reactions, learning and impact of training at work; and (4) analyze the relationships between individuals' previous experience in the topic of the training, participants' socio-demographic variables, psychosocial support and material support to the transfer of training impact to work, and (5) compare opinions of training participants with the opinions of bosses regarding the psychosocial and material support for the transfer of the impact of training on work.

\section{ASSESSMENT MODELS: LEARNING, REACTION AND IMPACT}

There are several evaluation models in TD\&E, including those primarily focused on variables of training results (Hamblin, 1978; Kenney \& Reid, 1986; Kirkpatrick, 1976; Philips, 1997) and those that include, in addition to results, the variables of context and other components of instructional systems: Context, Inputs, Results and Outputs - CIRO (Warr, Bird \& Rackham, 1970), Context, Inputs, Processes and Products - CIPP (Stufflebeam, 1978), the Integrated and Summative Evaluation Model - MAIS (Borges-Andrade, 1982) and the Integrated Model for Impact Assessment of Training at Work - IMPACT (Abbad, 1999).
The IMPACT model is made up by eight main components: (1) external environment, which assesses challenges, changes, opportunities and constraints; (2) psychosocial support that assesses the support offered by managers, coworkers and the organization so that the participant can attend the training and then apply at work the skills learned; material support, which assesses the quality, quantity, availability of resources and the adequacy of the physical workplace required to transfer to work the new skills learned in training; (3) needs, which assesses the nature and importance of learning demands 
and the magnitude of skill gaps; (4) clientele characteristics (sociodemographic, psychosocial, motivational and cognitive behavioral); (5) training characteristics (type of training knowledge, duration, nature of main objective, institutional background, educational level and instructor performance, characteristics of teaching material); (6) reactions, which is the measure of participants' perceptions about the programming, applicability, usefulness and outcomes of the training, in addition to the instructor's performance; (7) learning, which measures the degree of attainment of instructional objectives by participants at the end of a TD\&E action, (8) impact of training on the work (in depth: successful application at work of the CHAs acquired during instructional actions; in breadth: indirect influence of the training on the overall performance, attitudes and motivation of the graduate). This model was built based on the literature and assessment models such as those described by Passmore and Velez (2015). This survey analyzed the components 2) support, 4) clientele characteristics (sociodemographic), 6) reactions, 7) learning and 8) impact of training on work.

In order to identify and describe the main results of the research about reactions, learning and impact of training on work (also referred to in scientific publications as behavior at job, performance at work and transfer of training) a search for articles published from 2000 to 2015 in peer-reviewed journals was performed. Following are the main results of the analysis of these articles, divided into two parts: relationships between variables and predictive variables of training outcomes.

\section{RELATIONSHIPS BETWEEN REACTIONS, LEARNING AND IMPACT OF TRAINING ON WORK}

Initially, with regard to training results, Galanou and Priporas (2009) conducted an extensive study that intended to analyze the effect of six levels of assessment: reaction, learning, behavior at work, work performance, team performance and some broader effects on society. The authors found that training courses positively influenced managers 'expectations regarding the whole training process and positively affected managers' knowledge (learning). Still as a result of training, Laing and Andrews (2011) found a significant decrease in errors. For Zumrah (2014), training had a significant and positive relationship with training transfer.

Regarding the relationship between levels of assessment, reaction, learning and impact of training on work, Abbad, Borges-Andrade and Gama (2000) found that reactions are strongly correlated with impact, but weakly related with learning. Similarly, Abbad, Borges-Andrade, Gama, Morandini and Sallorenzo (2001) found that learning is not directly related to reaction or impact. Bastos (2012) found similar results in his study: he found a positive association between reaction and impact, weak relationship between reaction and learning, and lack of relationship between learning and impact.
In opposition to the national literature, in foreign literature, in the study by Tan, Hall and Boyce (2003), the results indicated that the cognitive reactions of employees are positively related to learning and behavior at job (impact) and that, in addition, negative affective reactions were better predictors of learning than favorable reactions. Homklin, Takahashi and Techakanont (2013) found in their study that reaction was positively related to learning and that learning was positively related to transference. Rowold (2007) found that satisfaction with training (reaction) showed no significant relationship with learning. Homklin et al. (2014) found again that the effect of learning on training transfer was positive and statistically significant.

Just like in the Brazilian surveys, foreign results are not unanimous in pointing out significant correlations between the three levels, nor consistent in indicating the direction and magnitude of the relationships between learning and the other levels. Among the five aforementioned objectives of this study, the third objective was formulated to analyze the relationships between reactions, learning and the impact of training on work, as suggested by the inconsistent findings found in the literature.

\section{VARIABLES PREDICTIVE OF TRAINING RESULTS}

In the sample of articles studied, studies on training effects on the behavior of graduates (imp on work, transfer, behavior at job and correlates) prevailed. There are relatively few studies on learning in training that investigate all three levels in the same research.

Regarding variables predictive of training outcomes, Abbad et al. (2001) identified that training alone does not seem to be able to produce lasting effects on the participant's behavior, because the transfer of learning to work depends on the post-training context. Abbad and Lacerda (2003) found only three explanatory variables of self-assessment of the impact of training on work: psychosocial support, instrumental value of training, and participant's reaction to the instructor. Abbad and Meneses (2003) found that only psychosocial support perceived by participants and self-efficacy contributed to explain the variability of impact self-assessment, while the psychosocial support perceived by bosses and coworkers and number of instructors by class 
contributed to explain the variability of others' evaluation of the training impact. In Silva's study (2006), the psychosocial support for transference was confirmed as the strongest predictor of impact. Oliveira Neto (2009) found that the best predictor of impact was the variable of support to transfer, but the variable elapsed time since the end of the course was also positively correlated with impact.

Pereira (2009) found that motivation to transfer, external support, social and technical support, and managers' perception of performance management practices adopted by the company proved to be important predictors of impact. Bastos (2012) also found a strong relationship between support to transfer and impact. In the research conducted by Santos Junior (2012), the main predictive variables of both generalization and impact measures were psychosocial support, interpersonal relationships, and learning self-assessment. The results of the study by Bastos, Ciampone and Mira (2013) corroborate the previous findings: variables of support to transfer are strongly related to impact. Based on these findings, the variable of support to transfer is considered to be the best predictor of impact.

Regarding variables predictive of learning, in the study by Abbad and Borges-Ferreira (2009) results showed that age, school location, learning self-assessment, reactions to instructional procedures and course results explained a small but statistically significant portion of the variability of the final learning means. In the study by Homklin et al. (2013), social support directly affected change of behavior after training and moderated the relationship between learning and the graduate's behavior. The relationship between learning and behavior was moderated by motivation to transfer and social support. Similar results were found by Phamet al. (2012). The study showed that workplace factors such as supervisor support, job autonomy, and preferential support (support as needed by the trainee) were significantly associated with transfer of training.

Kontoghiorghes (2001) found that the most important variables to facilitate learning and transfer are, among others: support by the supervision and incentive for the application of new skills and knowledge, and intrinsic rewards for applying newly acquired skills and knowledge. Regarding variables predictive of learning, Ruud et al. (2012) indicated a positive correlation between education level and pre-test and post-test scores for each test in each session and the overall result. However, improvement did not vary among participants with different levels of education. The results of Rowold's study (2007) showed that, in addition to education and motivation to learn, expectation indicates significant prediction regarding learning.

Studying the variables predictive of impact of training on work, Homklin et al. (2014) found that supervisor support was not a significant predictor of training transfer and did not moderate the relationship between retained knowledge and transfer. Support from coworkers, in turn, had a significant and positive effect on the transfer of training and on the relationship between retained knowledge and transfer. Organizational support was not positively related to training transfer and did not moderate the relationship between retained knowledge and transfer. In the study by Cromwell and Kolb (2004), training graduates who reported to have received high levels of organizational support, supervisor support, and peer support, and who also participated in a peer support network reported higher levels of transfer of knowledge and skills.

The results found by Ma and Chang (2013) indicated that career planning and perceived organizational support resulted in better performance at work. Yotamo (2014) found that the variables gender, age group, experience in the civil service and year of graduation were not correlated with impact. The variable of support to transfer, once again, was positively correlated with impact.

The results of the research by Joo, Lim, and Park (2011) suggest that organizational support and learning flow have direct effects on learning transfer and student satisfaction with training. The study by Massenberg, Spurk and Kauffeld (2015) showed that social support increases the motivation to transfer learning, both at the level of the training graduate and at the level of work team. The results found by Chauhan, Ghosh, Rai and Shukla (2016) confirmed the influence of supervisor support and also indicated that the effect of peer support is greater than that of supervisors on the transfer of training to the work by the graduate.

The analysis of the national literature showed that there are relatively few studies about learning, and that the results found indicate weak or no relationship between learning and reactions and impact. The results of foreign studies show that favorable reactions to training are positively correlated with impact of training on work (transfer, behavior at job). However, the results of foreign surveys are not consistent about the direction (positive, negative) and size (low, medium, high) of the relationship between learning and the other levels of assessment. One of the hypotheses raised to explain these inconsistencies is the occurrence of errors associated with the lack of evidence of validity of self-assessed learning measures, widely used in research, and the infrequent use of non-perceptual measures based on performance (test performance, tests, troubleshooting). In an attempt to minimize these gaps and failures, this study developed a measure to assess learning, with items describing problem situations that simulate the reality of the graduate's work.

Another hypothesis associated with the inconsistent findings regarding relationships between learning and other levels is the lack of pre-tests of knowledge that could show potential differences in the initial repertoire of the training participants and allow measuring the training contributions to learning. Another gap pointed out in the literature is the infrequent use of the other's assessment of impact and support. These assessments made by training graduates' 
chiefs, colleagues or peers, when adopted, have shown positive correlations with impact self-assessments and support for training transfer. However, these results are not conclusive, indicating the need for further studies on these relationships. In brief, the analysis of the articles showed gaps, inconsistencies, research issues, empirical results and theoretical research models that supported the formulation of the following six hypotheses:

- H1: The participants' reactions to the course and to the instructor's performance are positively correlated with learning (Abbad et al., 2000; Abbad et al., 2001; Hamblin, 1978; Kirkpatrick, 1976).

- H2: The participants' reactions to the course and to the instructor's performance are positively correlated with the impact of training on work (Abbad et al., 2000; Abbad \& Lacerda, 2003; Bastos, 2012; Hamblin, 1978; Kirkpatrick, 1976).

- H3: Learning is positively correlated with selfassessment of the impact of training on work (Abbad et al., 2001; Hamblin, 1978; Kirkpatrick, 1976; Santos Junior, 2012).

- H4: The participants' perceptions about the psychosocial and material support are positively correlated with self-assessment of impact of training on work (Abbad \& Lacerda, 2003; Bastos, 2012; Bastos et al., 2013; Oliveira Neto, 2009; Pereira, 2009; Santos Junior, 2012; Silva, 2006).

- H5: Self-assessments of the impact of on work will neither vary because of the participants' previous experience with the topic of the course, nor because of the sociodemographic characteristics (gender, education, age, office and length of work in the organization) of the respondents. (Joo et al., 2011).

- H6: Participants' and senior officers' perceptions about psychosocial support, material support and impact of training on work do not differ (Abbad \& Meneses, 2003; Galanou \& Priporas, 2009; Homklin et al., 2013; Homklin et al., 2014; Pham et al., 2012; Santos Junior, 2012; Yotamo, 2014).

\section{METHOD}

This study, conducted in a Regulatory Agency, comprised the application of a questionnaire and of situational tests of learning assessment. The method adopted will be detailed below in terms of participants, instruments, data collection and analysis procedures. Chart 1 shows an overview of the survey.

\section{Participants}

The participants were 150 graduates of the training and 61 immediate supervisors of these graduates, totaling 211 individuals. Among participants, $70 \%$ were female, with mean age of 35.02 years $(\mathrm{SD}=7.35)$ and specialization was the prevailing education level $(29.3 \%)$. Pharmacy was the main undergraduate course (29.3\%), mean length of work at the organization was 5.4 years $(\mathrm{SD}=4.47)$ and $47.33 \%$ had previous experience on the topic of the training. In the group of immediate supervisors, there was a prevalence of females $(65.6 \%)$, the mean age of participants was 38.88 years $(\mathrm{SD}=6.8)$ and specialization was the predominant education level $(62.3 \%)$.

\section{Trainings Assessed}

The trainings assessed were Health Indicators, Drafting Standards and Goals and Indicators, with learning objectives that reach the level of creation of the Taxonomy of Anderson et al. (2001). The three trainings are corporate, face-to-face, short-term and included topics focused on the development

Chart 1

Research overview

\begin{tabular}{|c|c|c|c|}
\hline Objective & Participants & Instruments & Moment of application \\
\hline Assessment of reaction & Participants of trainings & $\begin{array}{l}\text { Scale of Reaction to the Course (ERC) and Scale of } \\
\text { Reaction to the Instructor's Performance (ERDI). }\end{array}$ & By the end of the training \\
\hline Assessment of learning & Participants of the training & Situational test & By the end of the training \\
\hline \multirow{2}{*}{$\begin{array}{l}\text { Assessment of } \\
\text { psychosocial and } \\
\text { material support }\end{array}$} & Participants of the trainings & $\begin{array}{l}\text { Scales of support to the transfer of training (EST) - } \\
\text { assessment by graduates }\end{array}$ & $\begin{array}{l}3 \text { months after the end of } \\
\text { the training }\end{array}$ \\
\hline & $\begin{array}{l}\text { Managers of the participants of the } \\
\text { trainings }\end{array}$ & $\begin{array}{l}\text { Scales of support to the transfer of training (EST) - } \\
\text { assessment by managers }\end{array}$ & $\begin{array}{l}3 \text { months after the end of } \\
\text { the training }\end{array}$ \\
\hline \multirow{2}{*}{$\begin{array}{l}\text { Assessment of impact } \\
\text { in amplitude }\end{array}$} & Participants of the trainings & $\begin{array}{l}\text { Scale of self-assessment of the impact of training on } \\
\text { work - measured in amplitude }\end{array}$ & $\begin{array}{l}6 \text { months after the end of } \\
\text { the training }\end{array}$ \\
\hline & $\begin{array}{l}\text { Managers of the participants of the } \\
\text { trainings }\end{array}$ & $\begin{array}{l}\text { Scale of the other's assessment of the impact of } \\
\text { training on work -measured in amplitude }\end{array}$ & $\begin{array}{l}6 \text { months after the end of } \\
\text { the training }\end{array}$ \\
\hline
\end{tabular}


of technical analysis and problem-solving skills, and the creation of new work procedures.

\section{Instruments}

Five instruments were used for data collection. The instrument used to assess reactions consists of the Course Reaction Scale (ERC) and the Reaction to Instructor's Performance Scale (ERDI) (Abbad, Zerbini et al., 2012). The ERC comprises 24 items related to programming, applicability, utility, results and expected support, and has satisfactory evidence of validity and reliability in the sample researched $(\mathrm{N}=95 \%$ of total explained variance $=0.38$, factor loadings ranging from 0.31 to 0.80 and Cronbach's Alpha $=0.79$ ). The ERDI contains 15 items associated with a Likert scale, where 1 corresponds to poor and 5 to optimal. This scale has evidence of validity and reliability in the sample $(\mathrm{N}=111 \%$ of total variance $=47.16$; factor loadings ranging from 0.57 to 0.85 , Cronbach's alpha $=0.74$ ).

The instruments used to assess impact on amplitude were the Scale of assessment of impact of training on work and the Scale of other's assessment of impact-measured in amplitude. Both are composed of 12 items associated with a five-point Likert scale, where 1 corresponds to strongly disagree and 5 to totally agree with the statement. The self-assessment scale has evidence of validity $(\mathrm{N}=39 \%$ of total explained variance $=0.38$, factor loadings ranging from 0.41 to 0.87 and Cronbach's alpha $=0.87$ ), despite the small sample of respondents at this stage of this study. The questionnaire on support to transfer consists of 16 items related to Psychosocial Support and six items to Material Support to Transfer. Support items are associated with a Likert scale where 1 is never and 5 is always. Both scales have evidence of validity (Abbad, Sallorenzo et al., 2012). In this study, due to the size of respondents' sample (20), it was not possible to test the factorial structure of the instrument.

Specific situational tests were built to each of the three trainings, to assess learning. Responses to the items require participants to put into practice the technical skills acquired in the training, referring to the last level of complexity of the Taxonomy of Anderson et al. (2001), called creation, which includes analysis and problem solving. Tests were designed by the instructors of each training course, based on the educational objectives and the Learning Taxonomy of Anderson et al. (2001). Questions are open and contain problem situations that simulate the reality of work in the organization studied. The tests referring to Drafting Standards and Health Indicators contain three questions and the Goals and Indicators Workshop test has only two. The instructors to each training assigned scores from zero to one hundred to participants' answers to these openended questions, which were used in this study as learning assessment measures.

\section{Data Collection and Analysis Procedures}

Almost all data of this survey were collected through the application of questionnaires in electronic format. The links were e-mailed to respondents. The learning assessment was performed by the instructors who applied the tests in the classroom and corrected the answers according to technical quality criteria. All data collection observed ethical procedures to explain the research objectives, obtaining the consent of the participants, information about the possibility of withdrawing from the study at any time, and the confidentiality of answers. Participants' responses to the scales were analyzed using the SPSS version 22.0.

Descriptive analyses (arithmetic means, standard deviations, absolute and percentage frequencies, minimum and maximum values) and inferential analyses were performed using the nonparametric Mann-Whitney, Kruskal Wallis and Spearman Rho tests, considering that the assumption of normality for the use of parametric statistics was not met. The values used to calculate correlations were the mean of the participants' scores in the post-tests for the measure of learning and the means of the factors of the different scales: impact self-assessment, psychosocial support and material support (evaluations performed by the participants), others' assessment of impact and assessment of psychosocial and material support for transferring training to work, made by the leadership.

The test strength was calculated using the GPower 3.1.9.2 software (Goodwin and Goodwin, 2013), considering effect size 0.3 and $p=0.05$. The strength of each test will be presented along with the results of each analysis.

\section{RESULTS}

The descriptive results showed that participants had favorable opinions about psychosocial and material support, training and instructor's performance. However, the impact of training on work was considered medium, in the opinion of both graduates of the training and the managers. Table 1 presents the descriptive results of the evaluations performed by participants.
The main results showed that: (1) participants and their respective chiefs positively evaluated the psychosocial support to transfer training to work; (2) the means average assessment of reaction to the courses (Mean $=97.88$, $\mathrm{SD}=14.18)$ and the mean reactions to the instructor's performance (Average $=64.12, \mathrm{SD}=8.85$ ) indicated the participants' favorable opinions about trainings; (3) the 
Table 1

Means of factors of the instruments of assessment

\begin{tabular}{lcccccc}
\hline Instrument & Source & Sample size & Mean & $\begin{array}{c}\text { Standard } \\
\text { Deviations }\end{array}$ & Minimum & Maximum \\
\hline Psychosocial support & Participants & 21 & 54.71 & 10.49 & 34.00 & 72.00 \\
Material Support & Participants & 22 & 22.36 & 5.16 & 6.00 & 30.00 \\
Reaction to the course & Participants & 95 & 97.88 & 14.18 & 50.00 & 120.00 \\
Reaction to the instructor's performance & Participants & 100 & 64.12 & 8.85 & 43.00 & 75.00 \\
Impact of training on work - self-assessment & Participants & 39 & 41.21 & 7.32 & 22.00 & 54.00 \\
Impact of training on work & Management & 28 & 43.52 & 9.89 & 19.00 & 60.00 \\
Psychosocial support & Management & 29 & 59.68 & 5.54 & 51.00 & 70.00 \\
Material support & Management & 41 & 17.42 & 4.77 & 12.00 & 25.00 \\
\hline
\end{tabular}

mean scores of participants in the situational tests (Mean = 80.21, $\mathrm{SD}=26.62$ ) were high and favorable, and (4) means assigned to the impact of training on the work were median (41.21 in self-assessment. and 43.52 in others' assessment), when considering the scoring scale that ranged from zero to 60 points.

As regards the correlation between variables, $\mathrm{H} 1$ established that there would be a positive correlation between participants' reaction to the course and learning (participant grade in the situational test). Results showed that there was no correlation between reaction to course and learning, $r_{s}=0.199 \%$ BCa CI [-0.144, 0.515], $\mathrm{p}=0.189$ ( $p>0.05$ ), strength $=0.66, g l=43$ ). Moreover, there was no correlation between reaction to instructor's performance and learning, $r_{s}=0.245 \%$ BCa CI [-0.054, 0.507], $p=0.069$ $(\mathrm{p}>0.05)$, power $=0.75, \mathrm{gl}=54$. Therefore, $\mathrm{H} 1$ was not supported.

$\mathrm{H} 2$ predicted a positive correlation between reaction to the course and the impact of training on work. The results showed a significant and positive correlation between reaction to the course assessment and the impact selfassessment, $r_{s}=0.539 \%$ BCa CI [0.226, 0.782], $\mathrm{p}=0.003$ $(\mathrm{p}<0.05)$, power $=0.45, \mathrm{gl}=23$, i.e., the reaction to the course shares $29.05 \%$ of variance with the impact. However, the assessment of reaction to instructor's performance was not significantly related to impact, $r_{\mathrm{s}}=0.284 \% \mathrm{BCa} C \mathrm{CI}$ $[-0.119,0.625], \mathrm{p}=0.068(\mathrm{p}>0.05)$, strength $=0.50, \mathrm{gl}$ $=27$. Thus, $\mathrm{H} 2$ was partially corroborated, as there was a correlation between reaction to the course and impact selfassessment, but there was no correlation between instructor's performance and impact.

$\mathrm{H} 3$ established that there would be a positive correlation between learning and the impact of training on work. The results showed that there was no significant correlation between learning and training impact self-assessment, $\mathrm{r}_{\mathrm{s}}=$ $-2.5 \% \mathrm{BCa} C \mathrm{CI}-0,495,0,439], \mathrm{p}=0.455(\mathrm{p}>0.05)$, strength $=0.43, \mathrm{gl}=21$. Due to these results, $\mathrm{H} 3$ was not supported.

H4 estimated there would be a positive correlation between the two factors of support to transference (psychosocial and material) and the impact of training on work. The results showed that participants' assessment of psychosocial support for training transfer was positively and significantly related to the self-assessment of impact in amplitude, $\mathrm{r}_{\mathrm{s}}=6.76 \%$ BCa CI [0.99, 0.935], $\mathrm{p}=0.008(\mathrm{p}$ $<0.05$ ), strength $=0.26, \mathrm{gl}=10$, i.e., psychosocial support shares $45.7 \%$ of the variance with impact. However, material support for training transfer by participants was not significantly correlated with the self-assessment of impact of training on work, $\mathrm{r}_{\mathrm{s}}=-4.8 \% \mathrm{BCa}$ CI $[-0,600,0.604], \mathrm{p}=$ 0.438 ( $\mathrm{p}>0.05)$, strength $=0.28, \mathrm{gl}=11$. It is considered, therefore, that in the view of the graduates of the training, the psychosocial support was the only context variable correlated with the effects of training on the graduates' work.

The results also showed that psychosocial support, in the opinion of the graduates' supervisors, was not significantly correlated with the impact of others' assessment, $r_{\mathrm{s}}=-41.5 \%$, $\mathrm{BCa}$ CI [-0.992, 0.458], $\mathrm{p}=0.154(\mathrm{p}>0,05)$, strength $=$ $0.20, \mathrm{gl}=6$. The evaluation of material support by managers was not significantly correlated with the other's assessment of impact, $r_{s}=-2.4 \% \%$. BCa [-0.842, 0.923], $p=0.477$ ( $\mathrm{p}>0.05$ ), strength $=0.20, \mathrm{gl}=6$. Thus, $\mathrm{H} 4$ was partially confirmed.

H5 predicted there would be no difference in the impact of training on work due to previous experience and sociodemographic data of the training graduates. The variables considered were: previous experience of participants with the subject of the course, gender, education, position, age and length of work at the organization. However, only the length of work had a negative correlation with impact, $\mathrm{r}_{\mathrm{s}}=-0.375 \% \mathrm{BCa}$ CI $[-0.650,-0.029], \mathrm{p}=0.019$ $(\mathrm{p}<0.05)$, power $=0.61, \mathrm{gl}=37$, i.e., those with shorter length of work reported greater impact of training on work. The results partially corroborated H5, as the impact did not co-varied with previous experience or with the other sociodemographic characteristics of the participants.

In order to assess whether there was agreement between graduates of training and immediate managers about the psychosocial and material support offered and the impact of training on work, $\mathrm{H} 6$ was established, estimating that there would be agreement of opinion. Analyzing the assessments 
assigned by graduates and managers to psychosocial support, it was found that there was no significant difference, $\mathrm{U}=$ $2.00, \mathrm{z}=-1.50, \mathrm{p}=0.135(\mathrm{p}>0.05), \mathrm{r}=0,25$, strength $=0.54, \mathrm{gl}=50.52$. The same occurred when comparing means grades given by graduates and managers to material support, $\mathrm{U}=12.50, \mathrm{z}=-0.60, \mathrm{p}=0.549(\mathrm{p}>0.05), \mathrm{r}=-0,1$, strength $=0.57, \mathrm{gl}=57.20$. Comparing the self and the other' assessment of impact in amplitude, the Mann-Whitney test also found no significant differences between the opinion of graduates and managers, $U=11.50, z=-0.25, p=0.804$ $(\mathrm{p}>0.05), \mathrm{r}=-0.28$, strength $=0.78, \mathrm{gl}=103.04$. H6 was therefore corroborated.

\section{DISCUSSION}

This research intended to confirm the relationship between reactions and learning and between reactions and impact through hypotheses $\mathrm{H} 1$ to $\mathrm{H} 2$. The results showed that there is no correlation between reaction to the course and learning, neither between reaction to instructor's performance and learning. The results confirm the findings of Abbad et al. (2000) and Bastos (2012), who found weak correlation between reaction and learning, and by Abbad et al. (2001) and Rowold (2007), who found that learning is not directly correlated with reaction. However, this research supports the findings of Tan et al. (2003) and Homklin et al. (2013), who observed that cognitive reactions of employees are related to learning. The results also showed a positive correlation between participants' reaction to the course and the impact self-assessment. This result confirms the findings of Abbad et al. (2000), Tan et al. (2003), Abbad and Lacerda (2003), Galanou and Priporas (2009) and Bastos (2012).

The results indicated there is no significant correlation between learning and training impact self-assessment, contrary to the assumption of Kirkpatrick (1976) and Hamblin (1978) and the findings of Homklin et al. (2013) and Homklin et al. (2014), but corroborating the study by Abbad et al. (2001) and Bastos (2012). The fact that a person learned does not ensure that he or she will transfer the new learning to work, since learning seems to be a necessary but not sufficient condition for the application of learning acquired in training (Meneses, Zerbini \& Abbad, 2011). In this research, which adopted learning assessment measures more compatible with the complexity and nature of work situations in which the student will have the opportunity to apply the new learning, this relationship between learning and impact at work was not found. Training may have provided opportunities for learning, as revealed by the test results. However, the class hours of the courses may have been insufficient to ensure the use of instructional strategies favorable to the memorization of contents and the generalization of knowledge and skills to the work context. Other factors may have influenced the relationship between learning and impact, including the lack of opportunities for graduates to apply the skills learned during training.

The results revealed that the psychosocial support self-assessment was positively and significantly related to the self-assessment of impact in amplitude. However, the material support self-assessment was not significantly correlated with the self-assessment of impact on the graduate's work. The new skills acquired in the trainings analyzed examined did not require equipment and materials other than those already used by the workers in their daily work. Thus, the support of managers and colleagues was much more important for the transfer to work of the new skills acquired in the three trainings analyzed. This result contradicts the findings of Homklin et al. (2014), who found that the support of supervisors and colleagues was not positively related to training transfer (variable correlated to impact), but confirms results from several studies (Abbad \& Lacerda, 2003; Abbad \& Meneses, 2003; Cromwell \& Kolb , 2004; Silva, 2006; Pereira, 2009; Joo et al., 2011; Bastos, 2012; Santos Junior, 2012; Pham et al., 2012; Bastos et al., 2013; Homklin et al., 2013).

In this study, regarding $\mathrm{H} 5$, the variables previous experience, gender, education, position, age and length of work with the topic of the training were not correlated with impact, supporting the findings by Abbad and Carvalho (2006), which showed that age and education are not correlated with impact.

H6 estimated there would be no significant difference of opinion between participants and managers in the assessments of psychosocial support, material support and impact of training on work. This hypothesis was corroborated, what can be considered as very positive, since it suggests that participants and managers have similar views on support and impact, making the results more robust and reliable.

Regarding the tests strength, it was considered low or median, less than 0.80 in some cases for two reasons: 1) the small size of the samples, since the sample size directly interferes with the test strength, and 2) in the case of correlations with learning, the weak strength probably occurred due to the small number of questions in the situational tests resulted in the score used as a learning measure. To improve these tests, future studies should build more representative samples of the contents approached by the training. The lack of correlation between learning and other levels of assessment seems to be a problem regarding the psychometric quality of learning measures (selfassessments) commonly adopted in research. Situational tests based on instructor's assessment of the trainee's performance were adopted in this study in an attempt to verify whether these tests were more sensitive to detect correlations between learning and other levels of training assessment (reactions and impact) as assumed by traditional 
valuation models. These relationships, in future studies, should be further analyzed with larger sample sizes. Sample sizing analyses using the GPower showed that the strength of 0.80 , Alpha $=0.05$ and moderate effect sizes $=0.30$ would be achieved if the study counted on larger samples from participants. In addition, further studies should be performed to test the use of situational tests and seek evidence of the validity of situational measures in different contexts and training. Conducting the research in real environments is a huge challenge, as the researcher neither has control over the size of participants' sample, nor the return rate of questionnaires properly answered by participants.

\section{FINAL REMARKS}

This research showed the positive relationships between reactions and impact of training on work, supporting the findings of several studies in the area. The use of more than one source of information (graduates from training and leadership) in support and impact assessments, suggested as a research agenda by Abbad and Meneses (2003), Galanou and Priporas (2009), Pham et al. (2012) and Homklin et al. (2014), was important to reinforce the results.

The result of this research discloses yet another evidence of the positive correlation between support to transfer and the behavior of graduates at work evidenced in several national and international studies. This result has relevant practical implications, including the need to sensitize manager to the importance of supporting the transfer of training.

This research contributed to advance knowledge about learning, by building a measure based on situations that simulate the work of the participant in training, barely adopted in research in this field. However, the results of this study showed that learning is not correlated with reactions or impact of training on work. These findings contradict the hypotheses of positive correlations supported by traditional theoretical evaluation models such as Kirkpatrick's (1976), who consider learning as a necessary condition for the application at work of knowledge and skills acquired in training. These results that indicate no relationship between learning and reactions and impact are not conclusive, but raise research questions and flag the need for further studies that investigate how the relationships between learning, retention, generalization, and application of new learning occur and change over time and depending on the quality of the teaching outlines of the training (class hours for real life activities and simulation of application at work).
Among the main limitations of this research we could mention: (1) the number of learning assessment questions generated by instructors, which may have been insufficient to measure the number of education objectives of the trainings analyzed, and may have affected the validity of the tests content, (2) the selection of three short-term trainings with similar teaching outlines may have hindered the identification of variations in learning and application of that learning at work, and (3) the reduced size of the sample of respondents to the impact and support questionnaires.

This research also discloses the need for further studies that invest in the building of measures to assess learning with evidence of validity, based on real life scenarios or situations that simulate the reality of work, compatible with nature and complexity of the contents taught in corporate trainings. It also shows the need for studies that investigate, to each type of training and clientele profile: (i) how long learning is retained in the participants' memory, (ii) how long new learning stays in the graduate's repertoire, if the organization does not enable situations to apply that knowledge at work; and (iii) for how long a researcher should wait for a training to produce noticeable effects on the graduate's performance.

Time-related issues also point out the need for longitudinal studies that enable the analysis of the duration of training effects and the conditions require for applying the knowledge and skills learned through training at work. It is also important that further studies be conducted to understand the relationships between reactions, learning, impact on graduate's work, and other levels of assessment, as proposed by Tracey, Hinkin, Tannenbaum and Mathieu (2001), Montesino (2002) and Iqbal, Maharvi, Malik, Khan and Road (2011).

\section{REFERENCES}

Abbad, G. (1999). Um modelo de avaliação do impacto do treinamento no trabalho - IMPACT (Tese de doutorado). Universidade de Brasília, Brasília, DF, Brasil.

Abbad, G. S., \& Borges-Andrade, J. E. (2014). Aprendizagem humana em organizações de trabalho. In J. C., Zanelli, J. E. Borges-Andrade, \& A. V. B. Bastos (Orgs.). Psicologia, Organizações e Trabalho no Brasil (pp. 244-284). Porto Alegre: Artmed.
Abbad, G., Borges-Andrade, J. E., \& Gama, A. L. G. (2000). Treinamento: Análise do relacionamento da avaliação nos níveis de reação, aprendizagem e impacto no trabalho. Revista de Administração Contemporânea, 4(3), 25-45. doi: 10.1590/ S1415-65552000000300003

Abbad, G., Borges-Andrade, J. E., Gamas, A. L. G., Morandini, D., \& Sallorenzo, L. H. (2001). Projeto instrucional, aprendizagem, satisfação com o treinamento e autoavaliação de impacto do treinamento no trabalho. Revista Psicologia: Organizações 
e Trabalho, 1(2), 129-161. Recuperado de http://pepsic. bvsalud.org/scielo.php? script $=$ sci_arttext\&pid $=\mathrm{S} 1984$ $66572001000200006 \& \operatorname{lng}=$ pt\&tlng $=\overline{p t}$.

Abbad, G., \& Borges-Ferreira, M. F. (2009). Avaliação de aprendizagem em disciplinas de curso técnico a distância. Estudos de Psicologia, 14(2), 141-149. Recuperado de http:// www.scielo.br/pdf/epsic/v14n2/a07v14n2.pdf.

Abbad, G., \& Carvalho, R. S. (2006). Avaliação de treinamento a distância: Reação, suporte, transferência e impactos no trabalho.Revista de Administração Contemporânea, 10(1), 95-116. doi: 10.1590/S1415-65552006000100006.

Abbad, G., \& Lacerda, E. R. M. (2003). Impacto do treinamento no trabalho: Investigando variáveis motivacionais e organizacionais como suas preditoras. Revista de Administração Contemporânea, 7(4), 77-96. doi: 10.1590/ S1415-65552003000400005.

Abbad, G., \& Meneses, P. P. M. (2003). Preditores individuais e situacionais de auto e heteroavaliação de impacto do treinamento no trabalho. Revista de Administração Contemporânea, Edição Especial, 185-204. Recuperado de http://www.scielo.br/pdf/ $\mathrm{rac} / \mathrm{v} 7 \mathrm{nspe} / \mathrm{v} 7 \mathrm{nespa10.pdf}$.

Abbad, G., Pilati, R., Borges-Andrade, J.E., \& Sallorenzo, L.H. (2012). Impacto do treinamento no trabalho - medida em amplitude. In G. Abbad, L. Mourão, P. P. M. Meneses, T. Zerbini, J. E. Borges-Andrade, \& R. Vilas-boas (Orgs.), Medidas de Avaliação em treinamento, desenvolvimento e educação: fundamentos para gestão de pessoas (pp. 145-162). Porto Alegre: Artmed.

Abbad, G., Sallorenzo, L.H., Junior, F. A. C., Zerbini, T., Vasconcelos L., \& Todeschini, K. (2012). Suporte à transferência de treinamento e suporte à aprendizagem. In G. Abbad, L. Mourão, P. P. M. Meneses, T. Zerbini, J. E. BorgesAndrade, \& R. Vilas-Boas (Orgs.), Medidas de avaliação em treinamento, desenvolvimento e educação (pp. 244-263). Porto Alegre: Artmed.

Abbad, G., Zerbini, T., \& Borges-Ferreira, M. F. (2012). Medidas de reação a cursos presenciais. In G. Abbad, L. Mourão, P. P. M. Meneses, T. Zerbini, J. E. Borges-Andrade, \& R. Vilas-boas (Orgs.). Medidas de avaliação em treinamento, desenvolvimento e educação: fundamentos para gestão de pessoas (pp. 145-162). Porto Alegre: Artmed.

Anderson, L. W., Krathwohl, D. R., Airasian, P. W., Cruikshank, K. A., Mayer, R. E., Pintirch, P. R., Raths, J., \& Wittrock, M. C. (2001). A Taxonomy for learning, teaching and assessing: A revision of Bloom's taxonomy of educational objectives. New York: Longman.

Bastos, L. F. L. (2012). Avaliação da reação, aprendizagem e impacto de treinamento em um hospital do municipio de São Paulo (Dissertação de Mestrado). Universidade de São Paulo, São Paulo, SP, Brasil. Recuperado de file://C:/Users/admin/ Downloads/Lucelia_Bastos\%20(2).pdf.

Bastos, L. F. L., Ciampone, M. H. T., \& Mira, V. L. (2013). Avaliação de suporte à transferência e impacto de treinamento no trabalho dos enfermeiros. Revista Latino-Americana de Enfermagem, 21(6), 1274-1281. doi: 10.1590/0104-1169.2913.2364.

Borges-Andrade, J. E. (1982). Avaliação somativa de sistemas instrucionais: integração de três propostas. Tecnologia Educacional, 11(46), 331-342.

Chauhan, R., Ghosh, P., Rai, A. \& Shukla, D. (2016), The impact of support at the workplace on transfer of training: A study of an Indian manufacturing unit. International Journal of Training and Development, 20, 200-213. doi:10.1111/ijtd.12083.

Creswell, J. W., \& Clark, V. L. (2013). Pesquisa de métodos mistos. Porto Alegre: Penso.

Cromwell, S. E., \& Kolb, J. A. (2004). An examination of workenvironment support factors affecting transfer of supervisory skills training to the workplace. Human Resource Development Quarterly, 15(4), 449-471. doi: 10.1002/hrdq.1115.
Galanou, E., \& Priporas, V. (2009). A model for evaluating the effectiveness of middle managers' training courses: evidence from a major banking organization in Greece. International Journal of Training and Development, 13(4), 221-246. DOI: $10.1111 / \mathrm{j} .1468-2419.2009 .00329 . x$

Goodwin, C. J., \& Goodwin, K. A. (2013). Research in psychology: Methods and design. USA: Wiley.

Hamblin, A. C. (1978). Avaliação e controle do treinamento. São Paulo: McGraw-Hill do Brasil.

Homklin, T., Takahashi, Y., \& Techakanont, K. (2013). Effects of individual and work environment characteristics on training effectiveness: Evidence from skill certification system for automotive industry in Thailand. International Business Research, 6(12), 1-17. doi: 10.5539/ibr.v6n12p1.

Homklin, T., Takahashi,Y., \& Techakanont, K. (2014). The influence of social and organizational support on transfer of training: evidence from Thailand. International Journal of Training and Development, 18(2), 116-131. doi: 10.1111/ijtd.12031.

Iqbal, M. Z., Maharvi, M. W., Malik, S. A., Khan, M. M., \& Road, P. (2011). An empirical analysis of the relationship between characteristics and formative evaluation of training. International Business Research, 4(1), 273-286. doi: http:// dx.doi.org/10.5539/ibr.v4n1p273.

Joo, Y. J., Lim, K. Y., \& Park, S. Y. (2011). Investigating the structural relationships among organizational support, learning flow, learners' satisfaction and learning transfer in corporate e-learning. British Journal of Educational Technology, 42(6), 973-984. doi:10.1111/j.1467-8535.2010.01116.x.

Kenney, J., \& Reid, M. (1986). Training interventions. London: IPM.

Kirkpatrick, D. L. (1976). Evaluation of training. In R. L. Craig \& L. R. Bittel (Eds.), Training and Development Handbook (pp. 87-112). New York: McGraw Hill.

Kontoghiorghes, C. (2001). Factors affecting training effectiveness in the context of the introduction of new technology - A US case study. International Journal of Training and Development, 5(4), 248-260. doi: 10.1111/1468-2419.00137.

Laing, G. K., \& Andrews, P. (2011). An empirical test of training outcomes in the Australian hotel industry. International Journal of Business and Social Science, 2(21), 81-87. Recuperado de http://ijbssnet.com/journals/Vol 2 No 21 Special Issue November_2011/10.pdf.

Ma, C., \& Chang, H. (2013). Training transfer in the Taiwanese hotel industry: Factors and outcomes. Social Behavior and Personality, 41(5), 761-776. doi: 10.2224/sbp.2013.41.5.761.

Massenberg, A. C., Spurk, D., \& Kauffeld, S. (2015). Social support at the workplace, motivation to transfer and training transfer: A multilevel indirect effects model. International Journal of Training and Development, 19, 161-178. doi:10.1111/ ijtd.12054.

Meneses, P., Zerbini, T., \& Abbad, G. (2011). Manual de treinamento organizacional. Porto Alegre: Artmed.

Montesino, M. U. (2002). Strategic alignment of training, transferenhancing behaviors, and training usage: A posttraining study. Human Resource Development Quarterly, 13(1), 89-108. doi: 10.1002/hrdq. 1015 .

Oliveira Neto, F. S. (2009). Avaliação da efetividade de um curso de desenvolvimento de competências gerenciais (Dissertação de Mestrado). Universidade de Brasília, Brasília, DF, Brasil. Recuperado de 2017, de http://repositorio.unb.br/ handle/10482/8434.

Passmore, J., \& Velez, M.J. (2015). Training evaluation. In K. Kraiger, J.M. Passmore, N.R. Santos, \& S. Malvezzi (Eds.). The Wiley Blackwell Handbook of The Psychology of Training, Development, and Performance Improvement (pp. 136-153). Chichester, Wet Sussex: John \& Wiley Sons, Ltda.

Pereira, S. C. M. (2009). Avaliação, com base em modelo lógico, de efeitos de um treinamento estratégico no desempenho 
de egressos e da organização (Dissertação de Mestrado). Universidade de Brasília, Brasília, DF, Brasil. Recuperado de http://repositorio.unb.br/handle/10482/4688.

Pham, N. T. P., Segers, M. S. R., \& Gijselaers, W. H. (2012). Effects of work environment on transfer of training: empirical evidence from Master of Business Administration programs in Vietnam. International Journal of Training and Development, 17(1), 1-19. doi: 10.1111/j.1468-2419.2012.00417.x.

Philips, J. (1997). Return of investment in training and performance improvement programs. Houston: Gulf.

Rowold, J. (2007). Individual influences on knowledge acquisition in a call center training context in Germany. International Journal of Training and Development, 11(1), 21-34. doi: 10.1111/j.1468-2419.2007.00267.x.

Ruud, K. L., Leland, J. R., Liesinger, J. T., Johnson, M.G., Majka, A. J., \& Naessens, J. M. (2012). Effectiveness of a quality improvement training course: Mayo Clinic quality academy. American Journal of Medical Quality, 27, 130-138. doi: 10.1177/1062860611415391.

Santos Junior, A. B. (2012). Avaliação de impacto de um treinamento introdutório sobre o desempenho dos egressos (Dissertação de Mestrado). Universidade de Brasília, Brasília, DF, Brasil. Recuperado de http://repositorio.unb.br/handle/10482/12102.

Silva, M. E. (2006). Relações entre impacto do treinamento no trabalho e estratégia empresarial: $\mathrm{O}$ caso da Eletronorte. Revista de Administração Contemporânea, 10(3), 91-110. doi: 10.1590/S1415-65552006000300006.
Stufflebeam, D. (1978). Alternativas em avaliação educacional: um guia de auto-ensino para educadores. In M. Scriven \& D. Stufflebeam (Eds.). Avaliação educacional (II): Perspectivas, procedimentos e alternativas (pp. 50-150). Petrópolis: Vozes.

Tan, J.A., Hall, R. J., \& Boyce, C. (2003). The role of employee reactions in predicting training effectiveness. Human Resource Development Quarterly, 14(4), 397-411. doi: 10.1002/ hrdq. 1076.

Tracey, J. B., Hinkin, T. R., Tannenbaum, S., \& Mathieu, J. E. (2001). The influence of individual characteristics and the work environment on varying levels of training outcomes. Human Resource Development Quarterly, 12(1), 5-23. Recuperado de http://scholarship.sha.cornell.edu/ articles/948/.

Vargas, M. R. M., \& Abbad, G. (2006). Bases conceituais em treinamento, desenvolvimento e educação - TD\&E. In J. E. Borges-Andrade, G. S. Abbad, \& L. Mourão (Eds.), Treinamento, desenvolvimento e educação em organizações $e$ trabalho: Fundamentos para gestão de pessoas (pp. 137-158). Porto Alegre: Artmed.

Warr, P. B., Bird, M. W., \& Rackham, N. (1970). Evaluating of management training. Londres: Gower Press.

Zumrah, A. R. (2014). Service quality in Malaysian public sector: The role of transfer of training. Procedia - Social and Behavioral Sciences, 144, 111 - 117. doi: 10.1016/j. sbspro.2014.07.279. 